\title{
A Stylistic Analysis of Divine-Prophetic Discourse in Biblical and Quranic Texts
}

\author{
Riyadh Tariq Kadhim Al-Ameedi (Corresponding author) \\ Dept. of English, College of Education for Human Sciences, University of Babylon, \\ Babylon, Iraq \\ E-mail: alameedi.rtk@gmail.com \\ Manar Kareem Mehdi \\ Dept. of English, College of Education for Human Sciences, University of Babylon, \\ Babylon, Iraq \\ E-mail: manar.kareem90@gmail.com
}

Received: June 10, 2018 Accepted: July 10, 2018 Published: July 10, 2018

doi:10.5296/elr.v4i2.13377ＵRL: https://doi.org/10.5296/elr.v4i2.13377

\begin{abstract}
This paper attempts to identify the stylistic aspects of the language utilized in Divine-Prophetic discourse in Biblical and Quranic texts. Precisely, this work sets itself the task of answering the following question: what are the most prevalent stylistic devices implemented in this kind of discourse? Accordingly, the study aims at identifying the most common stylistic devices employed in Divine-Prophetic discourse and finding the interdifferences between Biblical and Quranic texts in this respect. It is hypothesized that Divine-Prophetic discourse utilizes certain stylistic techniques such as parallelism, repetition, alliteration, rhyme, simile, and metaphor. In order to achieve the aims of this paper and test its hypothesis, Leech and Short's (2007) categorization of figures of speech is utilized for the analysis of the data under scrutiny. Besides, a statistical method represented by the percentage equation is utilized for calculating the findings of analysis. The analysis is conducted on three Biblical texts taken from different books of the Old Testament and three Quranic texts taken from different suras of the Glorious Quran. Findings of the analysis reveal that the above hypothesis has been partially validated in the Biblical texts in that parallelism, repetition, alliteration, and simile have been widely implemented in these texts whereas rhyme and metaphor are not used at all. The same hypothesis, however, has been fully validated in the Quranic texts.
\end{abstract}


Keywords: Divine-Prophetic discourse, Stylistic analysis, Parallelism, Repetition, Alliteration, Rhyme, Simile, Metaphor

\section{Theoretical Underpinnings}

\subsection{Divine-Prophetic Discourse}

Allah's $\left({ }^{2}\right)$ purpose in providing and bestowing the gift of prophecy is clearly to re-establish and maintain communication with man, who has been estranged and separated from Him through sin. This gift operates through prophets, by means of visions, dreams, inspiration,

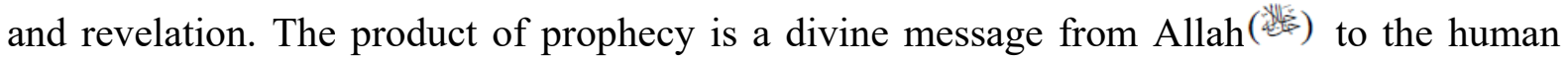
family, (Danielis, 1936: 22).

"The Hebrew word for prophet is nabi, derived from a verb signifying 'to bubble forth' like a fountain; hence the word means one who announces or pours forth the declarations of [Allah( $\left.\left.{ }^{\left({ }^{\prime}\right)}\right)\right]$. The English word comes from the Greek prophetes, which signifies in classical Greek one who speaks for another, especially one who speaks for a god, and so interprets his will to man" (Smith, 2002: 590).

(النبوة) 'prophecy' is one of the oldest phenomena in the life of humanity. This is due to the fact

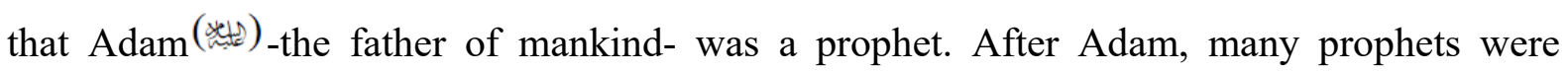
chosen by Allah( ${ }^{(1)}$ to transmit His message to people until the great mission of prophecy was sealed by Prophet Muhammad( (حسن) 2001: 5).

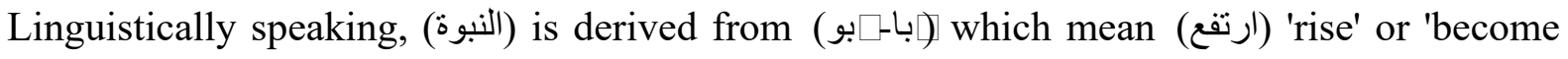
high'. Accordingly, (النبي) 'prophet' is someone who is higher in status than other human beings (القزويني, 1949: 385). As for the conceptual meaning of (النبوة), it means a human being

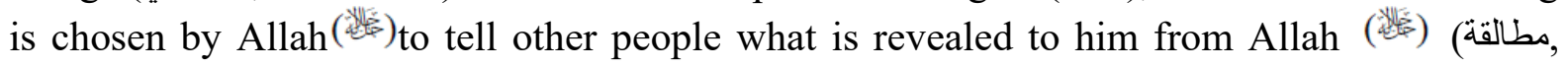
2013, 9).

As such, the linguistic meaning and the conceptual meaning of (النبوة) are closely related in that (النبي) 'prophet' is chosen by Allah(粘)to accomplish a sacred mission; so he is definitely higher in status than other human beings (Ibid.).

According to الطباـبائي (1997, vol. 18: 73-4), the following verse clarifies that there are three methods of communication between Allah( (糈) and His prophets(

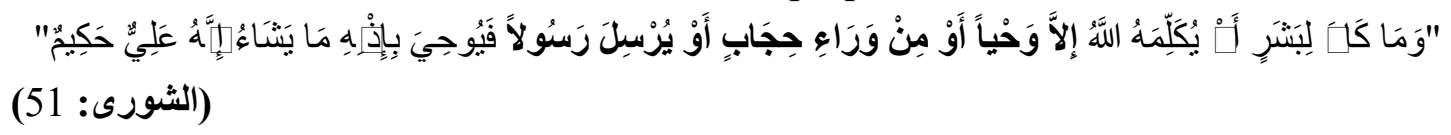

"It is not for any mortal that Allah should speak to him except by inspiration, or from behind a veil, or by the sending of a messenger to reveal, with Allah's permission, what Allah wills: for He is Most High, Most Wise." (Shakir, 1999: 237)

The first method is 'الوحي' (revelation) through which Allah(敞) without mediation (veil) or mediator (angel) like, for example, reveling something to the prophet while he is asleep. The second method is that Allah(

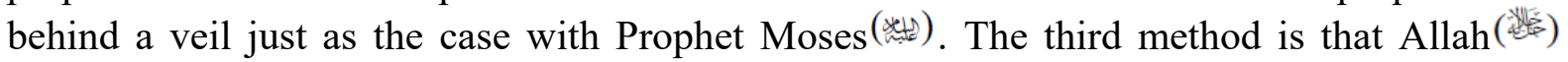
sends the Holy Spirit (جبريل) (ج) to deliver His message and commands to the prophet, i.e.

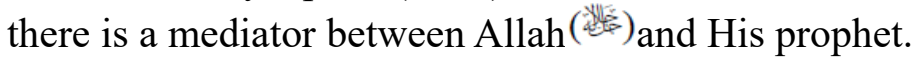




\section{Macrothink}

\subsection{Stylistic Means Utilized in Religious Texts}

The most common stylistic method utilized in religious texts is the employment of different figures of speech. Figures of speech refer to such features of the text which are foregrounded by means of departing in some way from general norms of communication such as "exploitation of regularities of formal patterning, or of deviations from the linguistic code". This heading consists of three subcategories. First we have grammatical and lexical foregrounded features (they include repetition, anaphora, parallelism, and chiasmus). The second subcategory is phonological schemes (they include rhyme, alliteration, and assonance). The third subcategory is tropes (it includes figures of speech such as metaphor, simile, metonymy, synecdoche, paradox and irony) (Leech \& Short, 2007: 60-4).

\subsubsection{Grammatical and Lexical Figures of Speech}

\subsubsection{Parallelism}

Parallelism is a relationship of partial identity between two sections of a text. "There are three major types of linguistic parallelism: syntactic, semantic, and phonological. In syntactic parallelism, the two sections of a text share some or all aspects of their syntactic structures (Fabb, 2003: 462). For instance,

"Ask, and it shall be given you; seek, and ye shall find; knock, and it shall be opened unto you." (Matthew, 7:7)

It is clear that the three sentences in the above verse have the same syntactic structure which is verb + coordinator + pronoun as a subject + verb phrase.

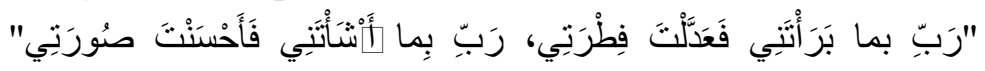

[الأمام الحسين (t), cited in AL-Ameedi and Mahdi, 2014: 40]

"O my Lord, as You originated me and did well my form; O my Lord, as You conferred favors on me and granted me wellbeing in myself." (Shahin, 2010: 972)

Similarly, in this example taken from Imam Hussein's( the two clauses have the same syntactic structure.

Semantic parallelism involves a pair of parallel words, one in each section of the text. "It is often common for syntactic parallelism to support semantic parallelism. In phonological parallelism, the phonological structures of the two sections of the text have some elements in common" (Ibid.: 463). It is convenient to mention that here we are concerned only with syntactic parallelism.

\subsubsection{Repetition}

Repetition is a powerful resource of interpersonal involvement and rapport and is often seen as one of the primary figures of speech. It may also be used for emphasis, or out of intensity of feeling. Repetition can appear in all linguistic levels. However, since lexical repetition is very obviously drawn to the attention, it is often therefore avoided in favour of variation by synonymy or substitution by pronouns, which are important means of cohesion (Wales, 2011: 366).

"My voice shalt thou hear in the morning, O LORD; in the morning will I direct [my prayer] unto thee, and will look up." (Psalms, 5:3) 


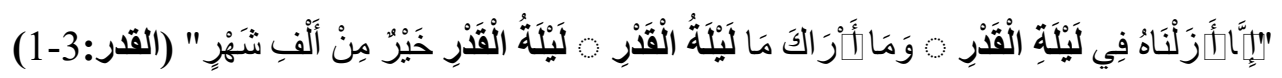

"Surely We revealed it on the grand night.And what will make you comprehend what the grand night The grand night is better than a thousand months." (Shakir, 1999: 309)

\subsubsection{Phonological Schemes}

\subsubsection{Rhyme}

Rhyme is a kind of phonetic echo found in verse: more precisely, a phonemic matching. In English, end rhyme is the most frequent type: "two units matched by identical sequences of sounds stretching from the vowel (usually stressed) to the end of the word, with the initial sound varied": e.g. June/moon; rose/toes. Such rhymes occur most commonly at the ends of metrical lines; within the lines they are called internal rhymes. And as rose/toes illustrate, it is sound, not spelling, that is primary. Identical spellings but with different pronunciations produce eye-rhyme, e.g. bough/ cough (Wales, 2011: 371). Here are examples of rhyme taken from the Holy Bible and the Glorious Quran respectively:

I will declare the decree:

The LORD hath said unto me,

Thou [art] my Son; this day have I begotten thee. (Psalms, 2:7)

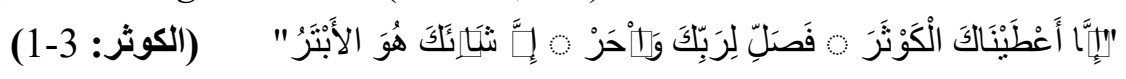

"Surely We have given you Kausar. Therefore pray to your Lord and make a sacrifice. Surely your enemy is the one who shall be without posterity." (Shakir, 1999: 312)

\subsubsection{Alliteration}

Alliteration refers to "the repetition of homophonous accented, syllable initial phonemes, as in house and home, cash and carry, tea for two, usually for stylistic or rhetorical effects" (Bussmann, 2006: 42).

"Thou hast also given me the shield of thy salvation: and thy right hand hath holden me up." (Psalms, 18:35)

"Let us break their bands asunder." (Psalms, 2:3)

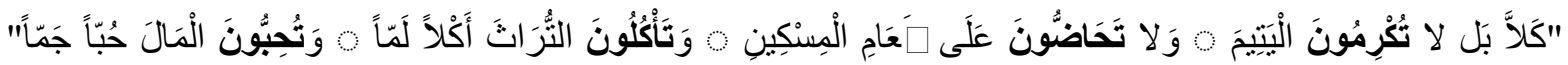

(الفجر: 20- (17-20)

"Nay! but you do not honor the orphan. Nor do you urge one another to feed the poor. And you eat away the heritage, devouring [everything] indiscriminately. And you love wealth with exceeding love." (Shakir, 1999: 305)

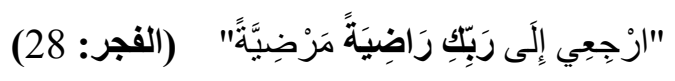

"Return to your Lord, well-pleased [with him], well-pleasing [Him]." (Shakir, 1999: 305) 1.2.3 Tropes

\subsubsection{Simile}

Derived from the Latin word (similis) which means 'like', simile is a figure of speech whereby two concepts are imaginatively and descriptively compared. Like and as are the commonest connectives in this respect; quasi-similes, however, involve the use of phrases like as if; resembling; suggesting, etc. (Wales, 2011: 383).

"He saw the Spirit of God descending like a dove, and lighting upon him." (Matthew, 3: 16) 


\section{Macrothink}

[Cited in Al-Ameedi and Al Shamiri, 2018: 234].

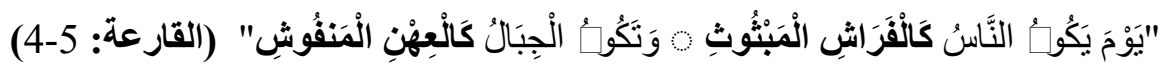

"The day on which men shall be as scattered moths. And the mountains shall be as loosened wool." (Shakir, 1999: 310)

\subsubsection{Metaphor}

Metaphor (from Greek meaning 'carry over') has sometimes been used "as a very general label for different kinds of figurative meaning or verbal transference, including metonymy and synecdoche". More usually, however, and more specifically, it is a very common figure or trope in rhetoric in which words are used with metaphoric senses, i.e., "one field or domain of reference is carried over or mapped onto another on the basis of some perceived similarity between the two fields" (Wales, 2011: 265):

"So the servants of the householder came and said unto him, Sir, didst not thou sow good seed in thy field?" (Matthew, 13:27)

In this verse, "good seed" is metaphorically used to refer to good people, i.e. those who respect and obey the Divine norms of Jesus Christ, his teachings, and his commands (Al-Ameedi \& Al-A'ssam, 2018: 87).

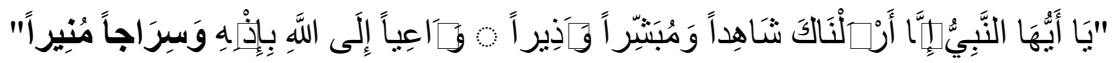

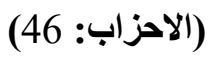

"O Prophet! surely We have sent you as a witness, and as a bearer of good news and as a warner. And as one inviting to Allah by His permission, and as a light-giving torch." (Shakir, 1999: 202)

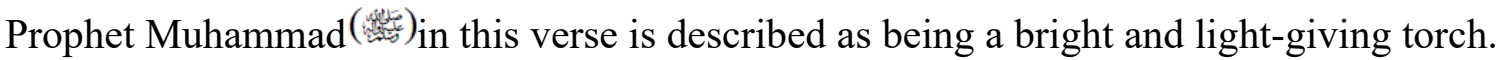

\section{Data Description and Analysis}

\subsection{Data Description}

The data of this study are represented by six texts consisting of Divine speech that Allah( ${ }^{\left({ }^{2}\right)}$ speaks to His Prophets after electing them to be His chosen men. Three of these texts are taken from different books of the Old Testament of the Holy Bible. The other three are taken from different suras of the Glorious Quran.

\subsection{Method of Analysis}

Each text is analyzed stylistically by following Leech and Short's (2007) model of figures of speech presented in Section (1.2).

\subsection{Data Analysis}

\subsubsection{Stylistic Analysis of Biblical Texts}

Text (1)

And, behold, the LORD stood above it, and said, I [am] the LORD God of Abraham thy father, and the God of Isaac: the land whereon thou liest, to thee will I give it, and to thy seed; And thy seed shall be as the dust of the earth, and thou shalt spread abroad to the west, and to the east, and to the north, and to the south: and in thee and in thy seed shall all the families of the earth be blessed. And, behold, I [am] with thee, and will keep thee in all [places] whither thou goest, and will bring thee again into this land; for I will not leave thee, until I have done 
[that] which I have spoken to thee of. (Genesis, 28:13-5)

Allah (此) addresses Prophet Jacob (知) in this text and repeats to him the covenant promises given earlier to Abraham and Isaac ( promising also to bring him back safely to Canaan.

From a stylistic perspective, this text implements four stylistic devices as Table 1 shows. Parallelism, here, reinforces the aesthetic value of this text via the rhythm and the musicality that it adds to the verses. This device, also, increases the unity and the smoothness of the text. Repetition and alliteration back up the connectivity of the text and make it more harmonious. 'Thy seed' is repeated for three times in the text because Allah( $\left.{ }^{\left(x^{\prime}\right.}\right)$ is promising His Prophet that He will multiply his seed and they will be like the dust of the earth. The simile used in this text (Thy seed shall be as the dust of the earth) serve to clarify and enhances the idea that

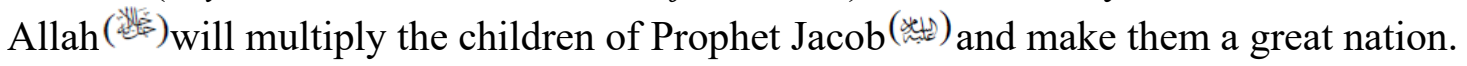

Table 1. Stylistic analysis of text (1)

Stylistic Analysis

Parallelism To the west, and to the east,

To the north, and to the south.

Repetition The Lord (2), God (2), land (2), thy seed (3), the earth (2), thou (3), thee (7).

Alliteration $\boldsymbol{B}$ e blessed.

Simile $\quad$ Thy seed shall be as the dust of the earth.

Text (2)

That the LORD appeared to Solomon the second time, as he had appeared unto him at Gibeon. \{9:3\} And the LORD said unto him, I have heard thy prayer and thy supplication, that thou hast made before me: I have hallowed this house, which thou hast built, to put my name there forever; and mine eyes and mine heart shall be there perpetually. $\{9: 4\}$ And if thou wilt walk before me, as David thy father walked, in integrity of heart, and in uprightness, to do according to all that I have commanded thee, [and] wilt keep my statutes and my judgments: $\{9: 5\}$ Then I will establish the throne of thy kingdom upon Israel for ever, as I promised to David thy father, saying, There shall not fail thee a man upon the throne of Israel. (1 Kings, 9:1-5)

Prophet Solomon ${ }^{(2 t)}$ has built a temple for His Lord to show that Allah( ${ }^{(3)}$ )is present among His people. In these verses, Allah( (㬎) addresses His Prophet telling him that He has accepted the temple and has blessed it (Fleming, 2005: 133-4).

From a stylistic standpoint, the text uses four stylistic devices that add aesthetic value to the text. Parallelism is implemented to add regularity to the text. Repetition is widely employed

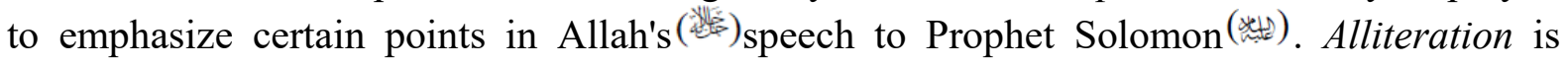
exploited to add harmony and smoothness to the text. 'Throne' is repeated for two times in the

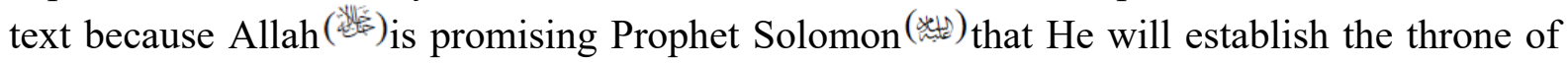
his kingdom upon Israel forever and that no man would take the throne from him. 
Table 2. Stylistic analysis of text (2)

Stylistic Analysis

Parallelism - Thy prayer and thy supplication.

- Mine eyes and mine heart.

- My statutes and my judgments.

Repetition The Lord (2), appeared (2), David thy father (2), Israel (2), heart (2) throne (2), walk-walked.

Alliteration Solomon the second, have heard, have hallowed, wilt walk.

Simile - And if thou wilt walk before me, as David thy father walked, in integrity of heart, and in uprightness.

Text (3)

And he said unto me, Son of man, go, get thee unto the house of Israel, and speak with my words unto them. $\{3: 5\}$ For thou [art] not sent to a people of a strange speech and of an hard language, [but] to the house of Israel; \{3:6\} Not to many people of a strange speech and of an hard language, whose words thou canst not understand. Surely, had I sent thee to them, they would have hearkened unto thee. \{3:7\} But the house of Israel will not hearken unto thee; for they will not hearken unto me: for all the house of Israel [are] impudent and hardhearted. $\{3: 8\}$ Behold, I have made thy face strong against their faces, and thy forehead strong against their foreheads. \{3:9\} As an adamant harder than flint have I made thy forehead: fear them not, neither be dismayed at their looks, though they [be] a rebellious house. \{3:10\} Moreover he said unto me, Son of man, all my words that I shall speak unto thee receive in thine heart, and hear with thine ears. $\{3: 11\}$ And go, get thee to them of the captivity, unto the children of thy people, and speak unto them, and tell them, Thus saith the Lord GOD; whether they will hear, or whether they will forbear. (Ezekiel, 3:4-11)

Stylistically, the text uses four stylistic devices that add aesthetic value to text. Parallelism is implemented to enhance the smoothness and harmony of the text. Repetition is extensively used to emphasize certain points in Allah's( ${ }^{\left({ }^{2}\right)}$ speech to His Prophet. 'A strange speech and an hard language' because Allah( ${ }^{\left(W^{\prime}\right)}$ emphasizes the fact that He is not sending His Prophet to a nation that speaks a strange speech or a hard language but to a nation whose language and speech he knows and understands very well. Alliteration is exploited, here, to create rhythm and to attract the attention of the addressee. Simile is employed here to clarify the idea that Allah( $\left.{ }^{\left({ }^{0}\right.}\right)$ has supplied His Prophet with sufficient strength to enable him to face whatever difficulties he may encounter while delivering Allah's ( $\left({ }^{\prime}\right)$ message. 
Table 3. Stylistic analysis of text (3)

Stylistic Analysis

Parallelism - Receive in thine heart, and hear with thine ears.

- Whether they will hear, or whether they will forbear.

Repetition A strange speech and an hard language (2), words (3),

go get thee (2), speak (3), hearken (2) - hearkened, people (3),

Israel (2), forehead (2) - foreheads, faces - face, strong (2),

house (3), hear (2), said (2).

Alliteration Sent-strange-speech, said-son, have the house, forehead fear,

go get, thee - them-they, have hearkened, Israel-impudent,

faces-forehead, whether-will.

Simile

As an adamant harder than flint have I made thy forehead.

\subsubsection{Stylistic Analysis of Quranic Texts}

Text (4)

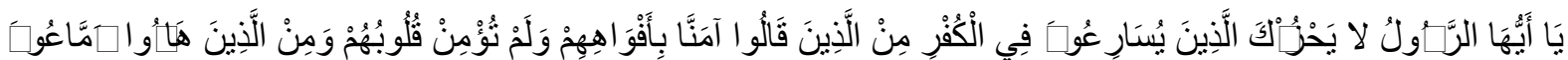

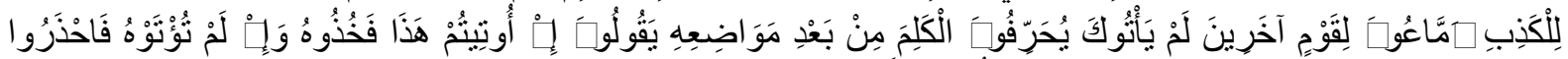

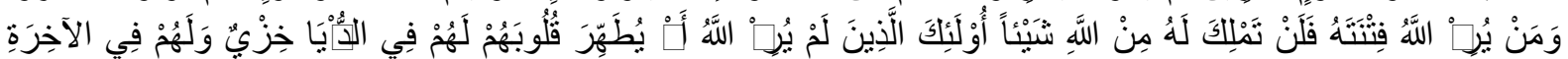

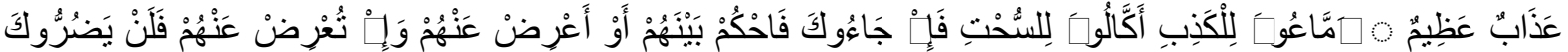

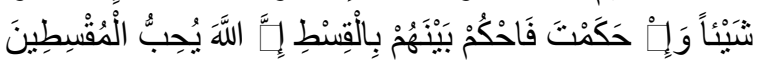

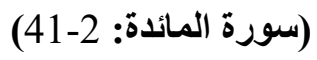

O Messenger! let not those grieve you who strive together in hastening to unbelief from among those who say with their mouths: We believe, and their hearts do not believe, and from among those who are Jews; they are listeners for the sake of a lie, listeners for another people who have not come to you; they alter the words from their places, saying: If you are given this, take it, and if you are not given this, be cautious; and as for him whose temptation Allah desires, you cannot control anything for him with Allah. Those are they for whom Allah does not desire that He should purify their hearts; they shall have disgrace in this world, and they shall have a grievous chastisement in the hereafter. [They are] listeners of a lie, devourers of what is forbidden; therefore if they come to you, judge between them or turn aside from them, and if you turn aside from them, they shall not harm you in any way; and if you judge, judge between them with equity; surely Allah loves those who judge equitably. (Shakir, 1999: 49-50)

This text uses three stylistic devices that add aesthetic value to the text. Parallelism is employed to increase the unity and harmony of the text giving it a smoother flow. Repetition

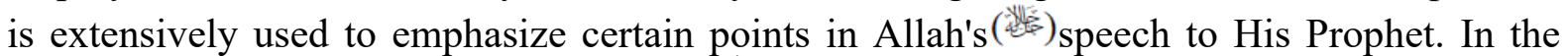

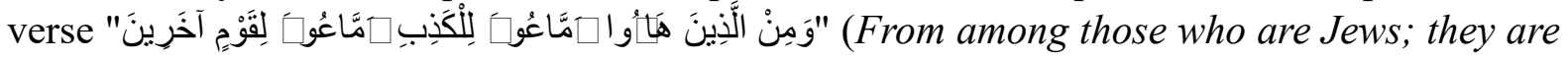
listeners for the sake of a lie, listeners for another people), we have the repetition of ( $\square$ ( $\square$ (

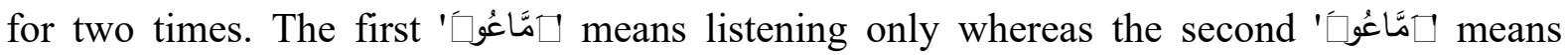




\section{Ml Macrothink}

accepting what they hear from those people and be obedient to them (الطبالـبائي, 1997, vol. 5: 346). Moreover, Alliteration is exploited, in this text, to create rhythm and to attract the attention of the addressee.

Table 4. Stylistic analysis of text (4)

\begin{tabular}{|c|c|}
\hline \multicolumn{2}{|c|}{ Stylistic Analysis } \\
\hline Parallelism & - \\
\hline Repetition & 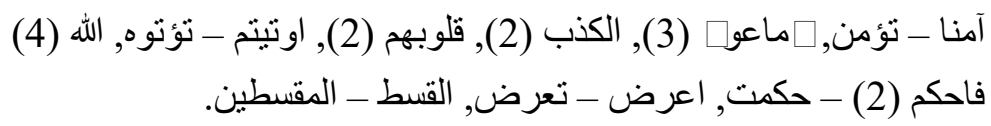 \\
\hline Alliteration & 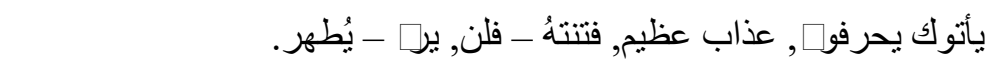 \\
\hline
\end{tabular}

Text (5)

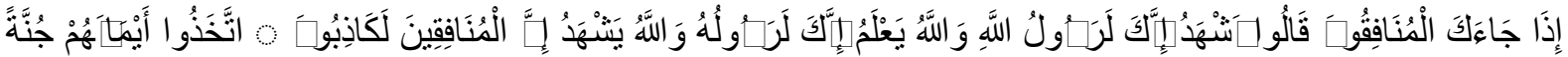

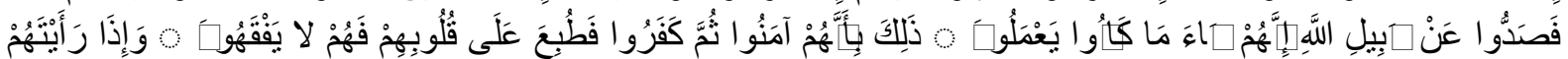

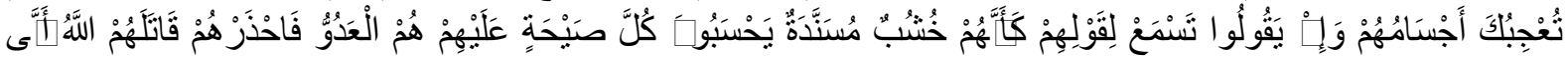

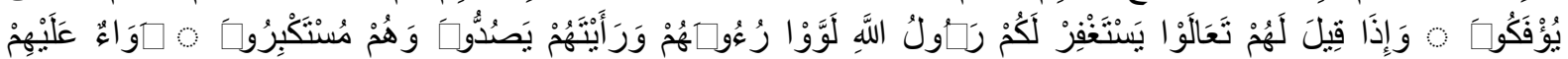

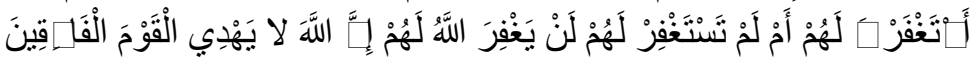

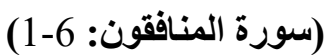

When the hypocrites come to you, they say: We bear witness that you are most surely Allah's Messenger; and Allah knows that you are most surely His Messenger, and Allah bears witness that the hypocrites are surely liars. They make their oaths a shelter, and thus turn away from Allah's way; surely evil is that which they do. That is because they believe, then disbelieve, so a seal is set upon their hearts so that they do not understand. And when you see them, their persons will please you, and If they speak, you will listen to their speech; [they are] as if they were big pieces of wood clad with garments; they think every cry to be against them. They are the enemy, therefore beware of them; may Allah destroy them, whence are they turned back? And when it is said to them: Come, the Messenger of Allah will ask forgiveness for you, they turn back their heads and you may see them turning away while they are big with pride. It is alike to them whether you beg forgiveness for them or do not beg forgiveness for them; Allah will never forgive them; surely Allah does not guide the transgressing people. (Shakir, 1999: 276)

Stylistically, the text utilizes five stylistic devices that add aesthetic value to the text.

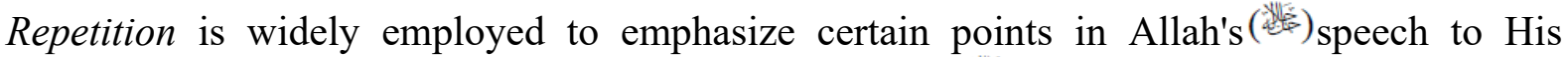

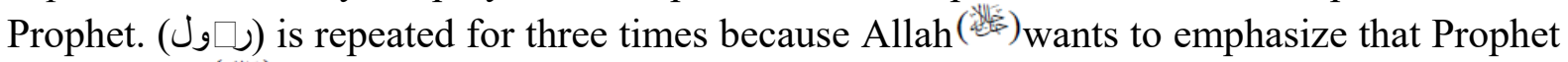

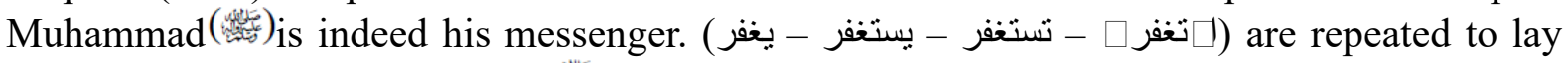
emphasis on the fact that Allah( $\left.{ }^{\left({ }^{2}{ }^{\prime}\right.}\right)$ will not forgive the hypocrites even if the Prophet asks forgiveness for them because Allah ( ${ }^{\left({ }^{2}\right)}$ does not guide those who are rebellious transgressors. Alliteration is exploited, here, to create rhythm and to attract the attention of the addressee. Rhyme employed adds harmony and smoothness to the text and creates connection between 


\section{MInstitute ${ }^{\text {Macrothink }}$}

the verses.

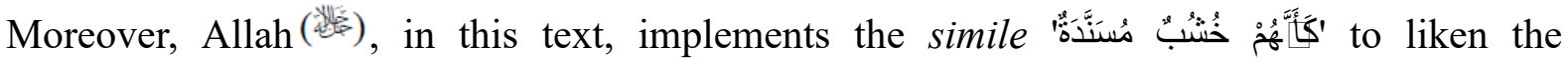
hypocrites to hollow pieces of timber or wood that are propped up on a wall or anything else because they are unable to stand on their own. Also, the oaths of these hypocrites are metaphorically described as being 'جَنَ', which means a cover or shield for their misdeeds.

Table 5. Stylistic analysis of text (5)

Stylistic Analysis

\begin{tabular}{|c|c|c|}
\hline Repetition & & 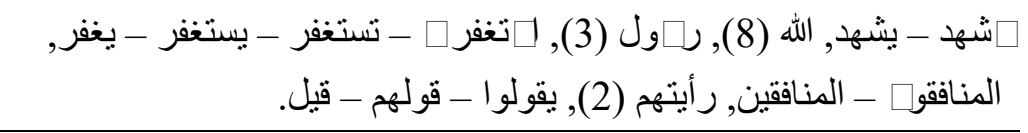 \\
\hline Rhyme & & 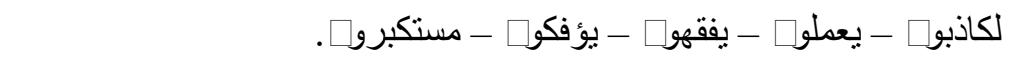 \\
\hline Alliteration & & 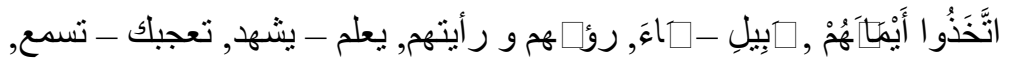 \\
\hline & & 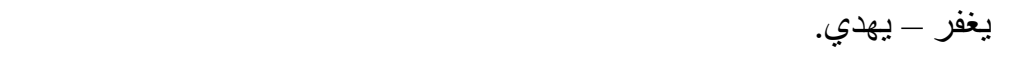 \\
\hline Simile & 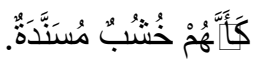 & \\
\hline Metaphor & 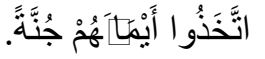 & \\
\hline
\end{tabular}

Text (6)

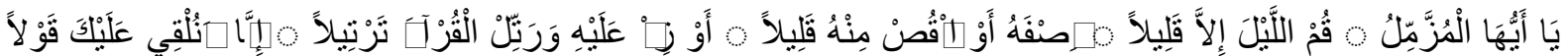

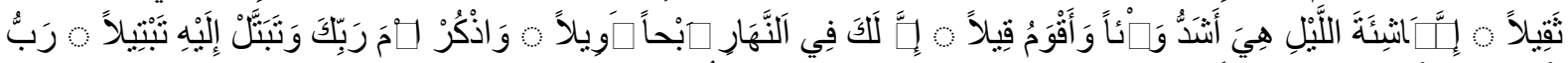

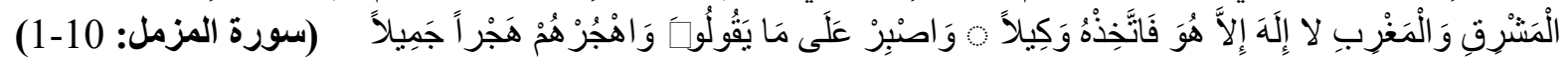
O you who have wrapped up in your garments! Rise to pray in the night except a little, Half of it, or lessen it a little, Or add to it, and recite the Quran as it ought to be recited. Surely We will make to light upon you a weighty Word. Surely the rising by night is the firmest way to tread and the best corrective of speech. Surely you have in the day time a long occupation. And remember the name of your Lord and devote yourself to Him with [exclusive] devotion. The Lord of the East and the West-- there is no god but He therefore take Him for a protector. And bear patiently what they say and avoid them with a becoming avoidance. (Shakir, 1999: 288)

From a stylistic perspective, the text utilizes four stylistic devices that add aesthetic value to the text. Repetition is extensively used to emphasize certain points in Allah's ( $\left({ }^{2}\right)$ speech to His Prophet. 'الليل' (night) is repeated for two times because Allah(粈) wants His Prophet to devote night to prayer and reciting the Glorious Quran. 'هجر' is also repeated for two times

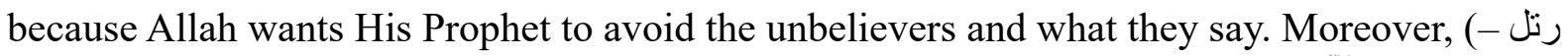
are also repeated to reinforce the point that Allah (ترتيلا, تبتل - تبتيلا, ربك - رب Prophet to pray to his Lord, to recite the Glorious Quran as it ought to be recited, and to raise his hands while imploring Allah( $\left.{ }^{(}{ }^{*}\right)$ and entreating Him. Rhyme employed adds harmony and smoothness to the text and creates connection between the verses. Alliteration utilized here serves to add regularity and smoothness to the text. The text, also, employs two metaphors.

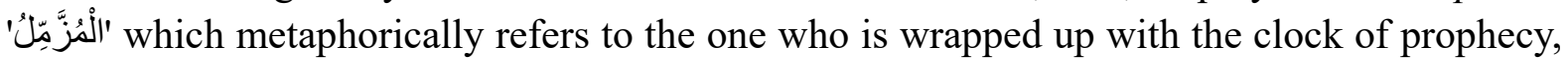

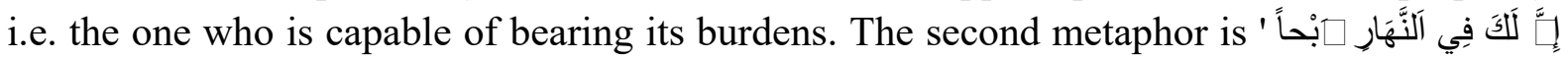


لَفِيلاً

Table 6. Stylistic analysis of text (6)

Stylistic Analysis

$$
\begin{aligned}
& \text { Repetition } \\
& \text { قليلا (2), رتل - ترتيلا, الليل (2), تبتل - تبتيلا, ربك - رب, اهجر هم - هجر ا. } \\
& \text { قليلا - ترنيلا - ثقيلا - قيلا - ـو يلا - تبتيلا - وكيلا - جميلا. }
\end{aligned}
$$

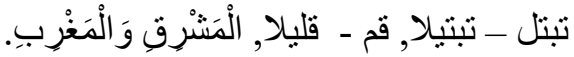

Metaphor

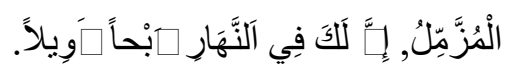

\subsection{Results of Analysis}

As Table (7) and Figure (1) below reveal, the most prevalent stylistic device utilized in Divine-Prophetic discourse in the Holy Bible is repetition with the percentage (52.83\%). This repetition is employed to emphasize certain points in Allah's $\left({ }^{(3)}\right)$ speech to His Prophets. Alliteration (28.30\%) is also a dominant stylistic device in this discourse. Parallelism (13.20\%) and simile (5.66\%) are less commonly implemented. Rhyme and metaphor are not used in this discourse.

Table 7. Results of Stylistic Analysis of Biblical Texts

\begin{tabular}{lllllll}
\hline No. of Text & Parallelism & Repetition & Rhyme & Alliteration & Simile & Metaphor \\
\hline (1) & 2 & 7 & 0 & 1 & 1 & 0 \\
$(2)$ & 3 & 7 & 0 & 4 & 1 & 0 \\
$(3)$ & 2 & 14 & 0 & 10 & 1 & 0 \\
Total & 7 & 28 & 0 & 15 & 3 & 0 \\
Percentage & $13.20 \%$ & $52.83 \%$ & $0 \%$ & $28.30 \%$ & $5.66 \%$ & $0 \%$ \\
\hline
\end{tabular}

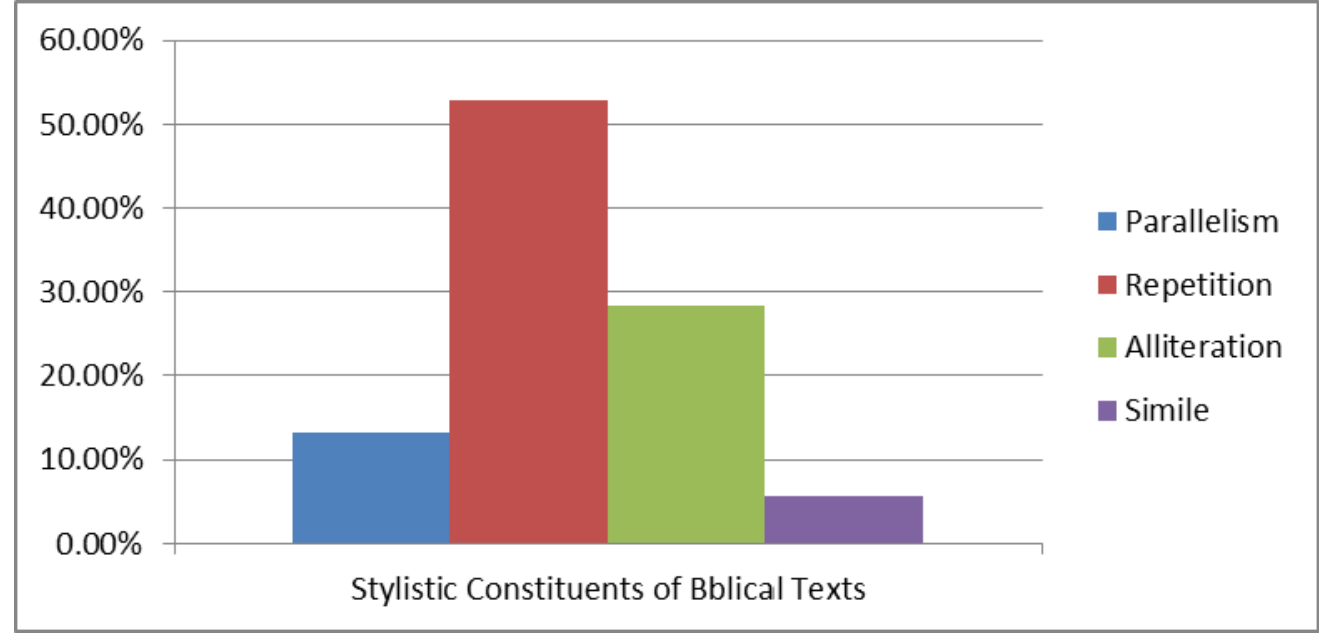

Figure 1. Ratio of Stylistic Constituents of Biblical texts 


\section{Macrothink}

Education and Linguistics Research

ISSN 2377-1356

2018, Vol. 4, No. 2

The most common stylistic device employed in Divine-Prophetic discourse in the Glorious Quran is repetition with the percentage (51.16\%). This repetition is used to emphasize and

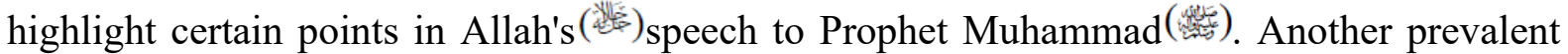
stylistic devices employed in this discourse are alliteration $(30.23 \%)$ and metaphor $(6.97 \%)$. These devices are exploited to add harmony and connectivity to this discourse. Parallelism and rhyme have the same percentage $(4.65 \%)$. Simile $(2.32 \%)$ scores the lowest percentage among other components as Table (8) and Figure (2) below show.

Table 8. Results of Stylistic Analysis of Quranic Texts

\begin{tabular}{lllllll}
\hline No. of Text & Parallelism & Repetition & Rhyme & Alliteration & Simile & Metaphor \\
\hline (4) & 2 & 9 & 0 & 4 & 0 & 0 \\
$(\mathbf{5 )}$ & 0 & 7 & 1 & 6 & 1 & 1 \\
(6) & 0 & 6 & 1 & 3 & 0 & 2 \\
Total & 2 & 22 & 2 & 13 & 1 & 3 \\
Percentage & $4.65 \%$ & $51.16 \%$ & $4.65 \%$ & $30.23 \%$ & $2.32 \%$ & $6.97 \%$ \\
\hline
\end{tabular}

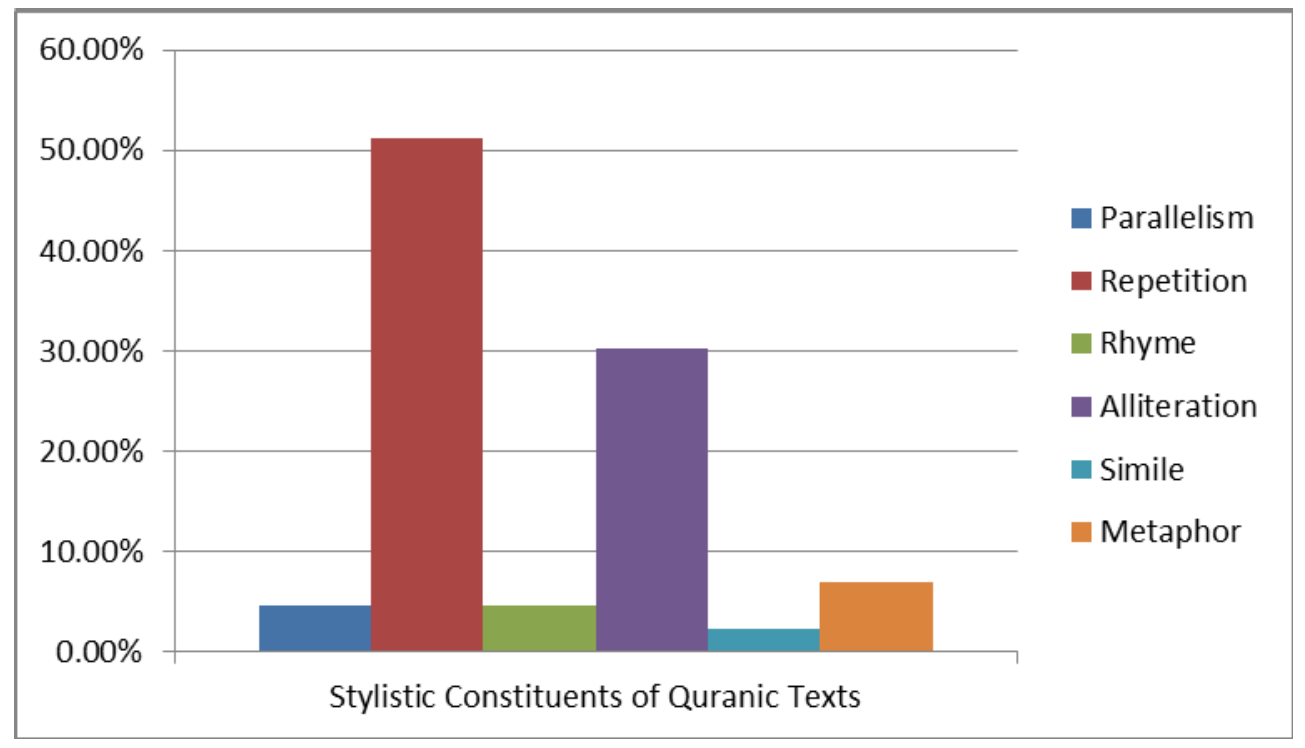

Figure 2. Ratio of Stylistic Constituents of Quranic texts

\section{Conclusions}

After conducting stylistic analysis on Biblical and Quranic data, the following conclusions can be presented:

1.) The hypothesis set at the beginning of this work has been partially validated in Biblical texts in that parallelism, repetition, alliteration, and simile have been widely implemented in these texts whereas rhyme and metaphor are not used at all. The same hypothesis, however, has been fully validated in Quranic texts.

2.) Both biblical and Quranic texts make extensive use of repetition in Divine-Prophetic 
discourse. This stylistic device serves to increase the unity of this kind of discourse in addition to its emphatic role in highlighting certain points in the Almighty Lord's speech to His Prophets.

3.) Other prevalent stylistic devices employed in this discourse are alliteration and parallelism. These devices are exploited to add harmony and connectivity to this discourse.

4.) Rhyme and metaphor are widely implemented in Divine-Prophetic discourse in Quranic texts but they are not employed in Biblical ones. This is due to the fact that the Holy Bible is translated from Hebrew into English so these stylistic devices could be lost through the process of translation.

5.) Simile scores the lowest percentage among other stylistic components in both Biblical and Quranic texts.

\section{References}

Al-Ameedi, R. T., \& Al Shamiri, S. A. (2018). Biblical Evaluative Discourse of Speech and Thought Presentation. International Journal of English Linguistics, 8(3), 223-238. https://doi.org/10.5539/ijel.v8n3p223

Al-Ameedi, R. T., \& Al-A'ssam, S. A. (2018). Retribution in Biblical Texts: A Stylistic Analysis. International Journal of English Linguistics, 8(4), 83-95. https://doi.org/10.5539/ijel.v8n4p83

Al-Ameedi, R. T., \& Mahdi, M. K. (2014). Imam Hussein's Supplication on the Day of Arafah: A Linguistic Analysis. AL-Ameed Journal, 3(12), 21-55.

Bussmann, H. (2006). Routledge Dictionary of Languge and Linguistics. London: Routledge. Danielis, A. G. (1936). The Abiding Gift of Prophecy. California: Pacific Press Association.

Fabb, N. (2003). Linguistics and Literature. In M. Aronoff, \& J. Rees-Miller, (Eds.). The Handbook of Linguistics. Oxford: Blackwell Publishing Ltd. https://doi.org/10.1002/9780470756409.ch18

Fleming, D. (2005). Bridgeway Bible Commentary. Brisbane: Bridgeway Publications.

Leech, G., \& Short, M. (2007). Style in Fiction. Harlow: Pearson Education Limited.

Shahin, B. (2010). Mafatih Al-Jinan (Keys to the Gardens of Paradise). Qum: Ansariyan Publications.

Shakir, M. H. (1999). The Quran. New York: Tahrik Tarsile Quran.

Smith, W. (2002). Smith's Bible Dictionary. Cambridge: Cambridge University Press.

The King James Version of the Holy Bible (PDF Version). 2004. Downloaded from: http://www.davince.com/bible

Wales, K. (2011). A Dictionary of Stylistics. London: Routledge. 


\section{Macrothink}

\section{Arabic References}

القرآن الكريم

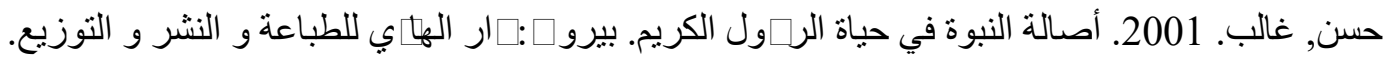

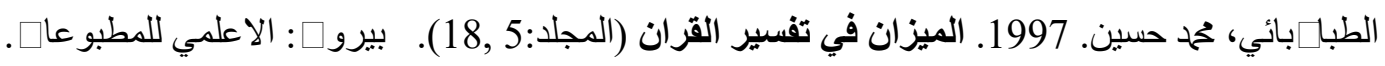

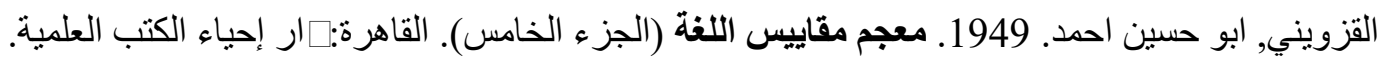

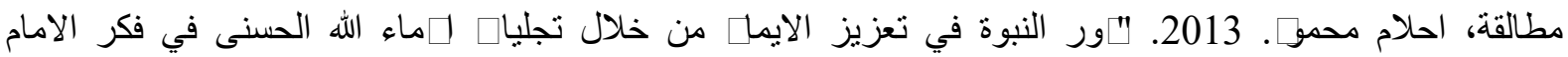

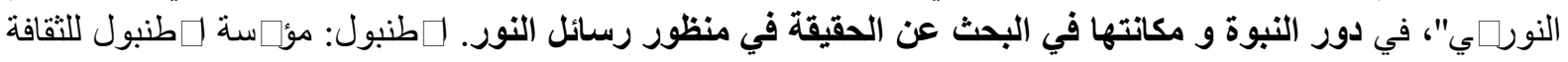

\section{Copyright Disclaimer}

Copyright reserved by the author(s).

This article is an open-access article distributed under the terms and conditions of the Creative Commons Attribution license (http://creativecommons.org/licenses/by/3.0/). 